\title{
Interest rate regulation, earnings transparency and capital structure: evidence from China
}

Article

Accepted Version

Li, X., Tian, L., Han, L. and Cai, H. (2019) Interest rate regulation, earnings transparency and capital structure: evidence from China. International Journal of Emerging Markets, 15 (5). pp. 923-947. ISSN 1746-8809 doi: https://doi.org/10.1108/IJOEM-04-2018-0164 Available at https://centaur.reading.ac.uk/87514/

It is advisable to refer to the publisher's version if you intend to cite from the work. See Guidance on citing.

To link to this article DOI: http://dx.doi.org/10.1108/IJOEM-04-2018-0164

Publisher: Emerald

All outputs in CentAUR are protected by Intellectual Property Rights law, including copyright law. Copyright and IPR is retained by the creators or other copyright holders. Terms and conditions for use of this material are defined in the End User Agreement.

www.reading.ac.uk/centaur 
Central Archive at the University of Reading

Reading's research outputs online 


\title{
Interest Rate Regulation, Earnings Transparency and Capital Structure: Evidence
}

\section{from China}

\begin{abstract}
We use samples from Chinese listed companies to investigate the effects of interest rate deregulation and earnings transparency on company's capital structure in China over the period of 2003-2015. In particular, we study the link between state-owned enterprises (SOEs), economic growth targets, and marketization in China's unique institutional context. The results show earnings transparency increases firm leverage and the additional tests suggest that such an effect takes place via a mechanism by reducing the cost of debt finance. However, information transparency could moderate the effects of interest rate deregulation on corporate capital structure. In addition, SOEs are less sensitive towards the changes of interest rates in China because lending to SOEs is policy-oriented and lacks of market evaluation of business risk. Government control is conducive to enhancing the transparency of the whole industry, however, market-oriented reform is conducive to enhancing the transparency of the company's own information. The results are robust to endogeneity tests and a variety of variable and model specifications. Lastly, we find that information transparency has little impact on equity financing because of IPO and SEO strictly controlled by the Chinese government. The paper makes contribution to the relationship between earnings disclosure quality and capital structure in the Chinese unique institutional context, such as taking the progressive interest rate reform, SOES, different economic growth target and different marketization level in each province of China. We suggest that investors will pay more attention to the company's own unique information transparency in the provinces with high degree of marketization. As a potential direction for future research, we will investigate how the earnings transparency has impact on capital structure, and how such impact would depend on the transparency of specific business, the cap of foreign shareholding and the convenience of investment.
\end{abstract}


Key words: Earnings transparency, Interest rate deregulation, Capital Structure, Economic growth targets, Marketization index

JEL classification: E52, G32, G38

\section{Introduction}

There has been a long-standing debate among economists regarding the effects of interest rates on the real economy (e.g., Bernanke and Gertler, 1995). Following the development of capital structure theories (e.g. Modigliani and Miller, 1958), recent studies on the determinants of corporate capital structure have shown that the financing decisions would heavily depend on financial characteristics and information environment (e.g. Booth et al., 2001; Öztekin, 2015). There would be an unfavorable effect of information asymmetries on debt financing (Jensen and Meckling, 1976) and firms typically have better information than outsiders about their business investment opportunities, causing the problems of information asymmetries and agency costs. To some extent, financial reporting and disclosure are potentially important for management to communicate corporate performance with external investors. Hence, as a vital component of accounting disclosures, earnings transparency can affect the decision-making of investors and the corresponding cost of capital (Barth et al, 2013). Goldstein et al (2019) find that disclosure negatively affects price in formativeness. To explore further this result, we decompose earnings transparency into earnings transparency of industry and the company's own earnings transparency. As a result, the earnings transparency would depend on the timing and content of firms' information disclosure. Firms can make timely and informative disclosures are perceived to have a lower likelihood of withholding value-relevant unfavorable information, firms would pay lower prices on debt finance and have a greater tendency to leverage up. 
Different from developed economies, China, as the largest emerging economy, has been experiencing a monetary regime that featured a regulated currency, a controlled capital account and a regulated domestic interest rate by central bank (Zhang et al., 2014) and so far pursued a financial liberalization strategy. Indeed, China has been gradually reforming its financial sector from early 1980s and the monetary policy environment has undergone a significant change. Especially, the pace of interest rate liberalization reforms have accelerated since 1996 by making the exchange rates more flexible and market-oriented, expanding the interbank money, bond, and stock markets, opening the banking sector to more competition and liberalizing interest rates. Chen and $\mathrm{Li}$ (2015) note that the reforms, that provide a distinct institutional environment and financing conditions, have changed the environment of business significantly. Along this line, Chen and $\mathrm{Ma}$ (2018) uses liberalization of the ceiling on deposit rates and floor on lending rates to test the impact of interest rate liberalization on loan availability. Zheng et al. (2018) uses the official launch of the Loan Prime Rate (LPR) Centralized Quotation and Publishing Mechanism, in order to test whether the interest rate liberalization affected the deleveraging of over-indebted firms. Zhao et al. (2019) suggest that the interest rate marketization, which reduced government intervention in fund pricing, helps alleviate financing constraints, especially for non-state-owned enterprises. These studies are helpful for understanding the effect of marketization of interest rates on debt financing.

Building upon the above studies, we can expect that after reforms, risk premium on loans should reflect more business risk-relevant information and there should be a stronger favorable effect of information transparency on capital structure (Francis et al., 2004). High quality earnings disclosures are required by lenders to capture changes in firm performance, which potentially enable firms to acquire more debt financing supports. However, they ignore the essential features of market-oriented reforms. Filling this gap, we use interest rate regulation to test the underlying mechanisms. Focusing on the interest rate liberalization reforms in China, 
we explore the relationship between earnings disclosure quality and debt financing behaviors of Chinese publicly listed companies. Besides, we shed new light on the interactions between earnings transparency and interest rate deregulation in the context of state owned firm, different economic growth target and different marketization level in each province of China.

In particular, we follow Barth et al. (2013) and construct an index of earnings transparency of Chinese listed companies from both intertemporal and cross-sectional perspectives. We find strong evidence that the more transparent the information, the more debt financing. However, informationally transparent firms would moderate the effects of interest rate deregulation on corporate capital structure. These findings are in consistent with those of Botosan (1997) who uses data from developed markets. In addition, we find that state-owned enterprises (SOEs) are less sensitive towards the changes of interest rates in China because lending to SOEs is policyoriented and lacks of market evaluation of business risk. We find that information transparency has little impact on equity financing because of IPO and SEO strictly controlled by the Chinese government. We suggest that economic growth target under the condition of deregulating interest rate the government's economic regulation is beneficial to the industry as a whole, however, it is not beneficial for individual enterprises. Furthermore, we suggest that investors will pay more attention to the company's own unique information transparency in the provinces with high degree of marketization. Finally, government control is conducive to enhancing the transparency of the industry, however, market-oriented reform is conducive to enhancing the transparency of the company's own information.

In a word, our research will help to understand the debt financing in the context of interest rate deregulation and find which is crucial to identify the real effects of the new economic regimes in China. In particular terms, we make contribution to the previous research from four aspects. Firstly, we decompose earnings transparency into earnings transparency of industry and the company's own earnings transparency. We also consider the interactive effects of 
information transparency and gradual interest rate liberalization on debt financing. Secondly, we suggest that that SOEs have an advantage over private firms in accessing debt finance with interest rate deregulation. Thirdly, we suggest that economic growth target is conducive to enhancing the transparency at the industry level, but not the firm's own transparency. Fourthly, we suggest that marketization in each province of China is conducive to enhancing firm's own transparency, bu not the transparency of the industry.

The remainder of the paper is organized as follows. In Section 2, we introduce the institutional background of interest rate regulation in China. We review literature and develop hypotheses in Section 3, and define the key variables and data in Section 4. We present our econometric results in Section 5 and conclusion in Section 6.

\section{The institutional background of interest rate regulation}

The 'supply-side' effect of credit market (De Janvry et al., 2010) on corporate leverage has attracted an increasing attention in academia, such as the market timing hypothesis (Baker and Wurgler, 2002) which claims that market timing is the first order determinant of capital structure. Therefore, corporate characteristics and capital market play a fundamental role in the determination of corporate capital structure and investment, such as information transparency and investment distortions (e.g. Wang et al., 2011).

However, capital market is not perfect in the emerging economies and in credit supply is mainly embodied in the high level of regulation, for example interest rate regulation in China. The interest rate control has been one of the most typical macro-regulatory functions used by government to regulate the supply of financial products (Huang and Wang, 2010), which have a significant impact on corporate financing and investment behavior. Currently, Chinese government has pledged to steadily put forward with the interest rate reform, and the particular institutional characteristics of the control are mainly reflected in two aspects. 
First, as the central bank in China, People's Bank of China (PBoC), is actively controlling the interest rates in accordance with the macro-economic conditions. Chinese government has adjusted interest rates significantly in the last decade in order to achieve a balance between maintaining relatively rapid and stable economic development and properly handling inflationary pressures. For example, the loan interest rate ceiling was released in 2004. However, the central bank lifted the one-year lending and deposit base rates six times to cope with excessive liquidity and inflationary pressures, while initiated a slew of interest rate reductions since September 2009 to deal with the international financial crisis in 2007 . On $7^{\text {th }}$ June 2012, the upper limit of the floating range of deposit rate in financial institutions was set at the 1.1 times of the base rate, the lower limit of loan rate was set at the 0.8 times, which is a breakthrough in the interest rate liberalization progress because it hands the capital pricing power over to the market to a greater extent. Lately, with the eliminating of the floor on lending rate on $19^{\text {th }}$ July 2013 , the liberalization of interest rates was fully implemented.

As shown in Figure 1, for example, Chinese government adjusted the lending rate (deposit interest rate) 1 (1) times in 2004 and 2014, 2 (1) times in 2006, 6 (6) times in 2007, 5 (4) times in 2008, 2 (2) times in 2010 and 2012, 3 (3) times in 2011 and 5 (5) times in 2015. In some other years, such as 2003, 2005, 2009 and 2013, there were no interest rate adjustment in China. 


\section{Figure 1 Number of adjustment of benchmark one-year lending and deposit rates}

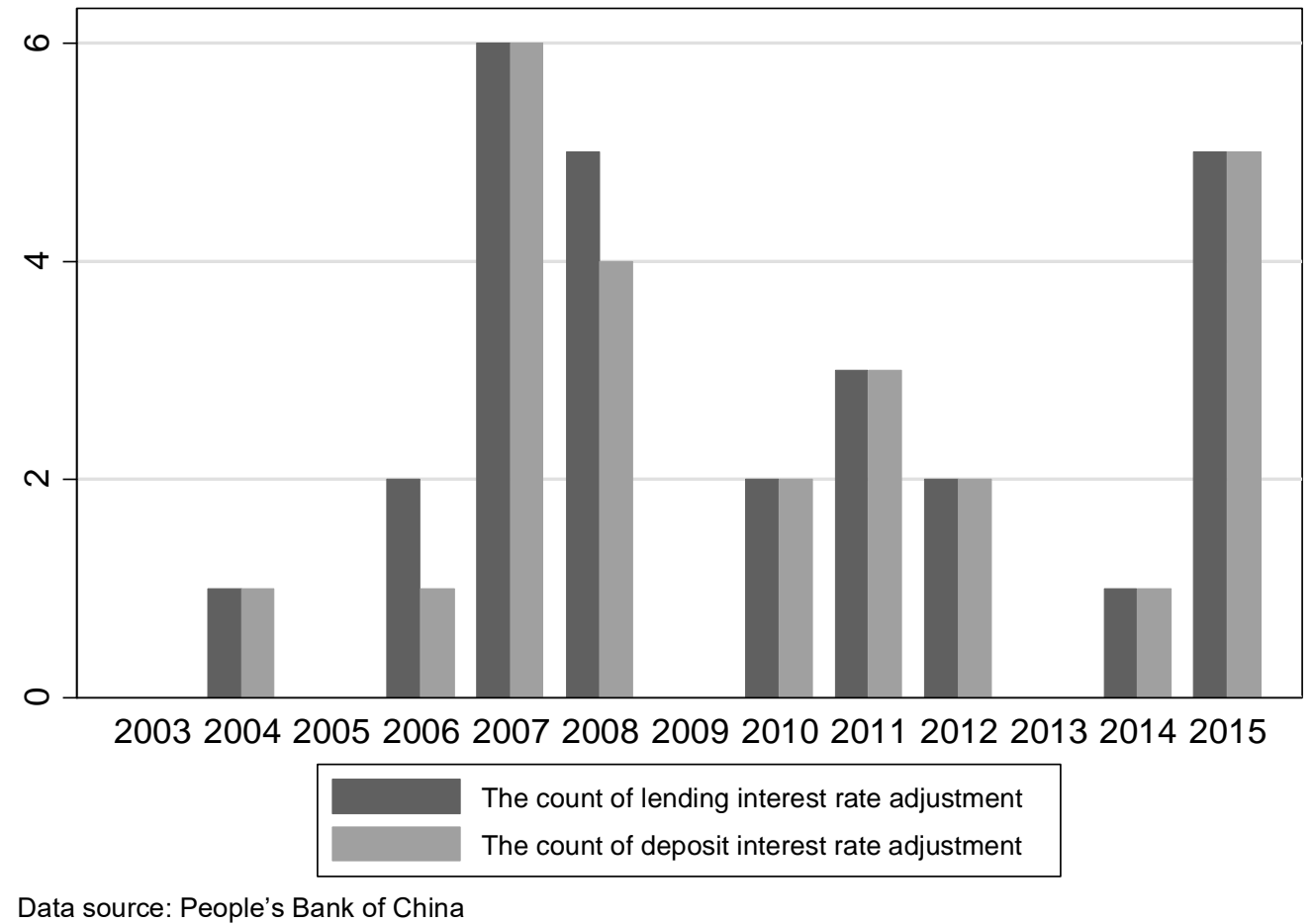

Second, China has been moving into a more market-oriented financial system by making substantial progress in liberalizing financial markets, and its interest rates in particular, show a distinct two-track system which is composed of a regulated rate and a market rate (Zhang, 2014). With the promulgation of interbank rate deregulation on $1^{\text {st }}$ June 1996 , the reform of interest rate liberalization started to implement across the whole country. For example, markets started to open for transactions on financial and government bonds since 1998, foreign currency loan interest rates were deregulated in 2000 , and the ceiling on lending rates were removed, allowing borrowing costs to vary up to a range of 10 percent lower than the base rate in 2004 . Subsequently, on $4^{\text {th }}$ January 2007, the Shanghai Interbank Offered Rate (SHIBOR) rates was officially launched. With financial market reform, interest rate liberalization is essentially a deregulating process that continually improves market forces and strengthens competition in banking sector. It not only builds a market-based capital allocation system outside the interest rate control, but also enables commercial banks to make loan pricing decision by themselves. 
Figure 2 shows the fluctuation of both lending and deposit rates during the liberalization process, and presents a certain degree of difference between regulated base rate and marketbased SHIBOR rates. There have been a large number of studies examining the effectiveness of interest rate liberalization in China, for example, the link between deregulation and economy growth (Chen et al., 2014). This paper therefore aims to complement the literature by focusing on the effect of earnings transparency to explore how the action of interest rate deregulation would affect corporate financing behavior.

Figure 2 Fluctuation of interest rates during the liberalization process
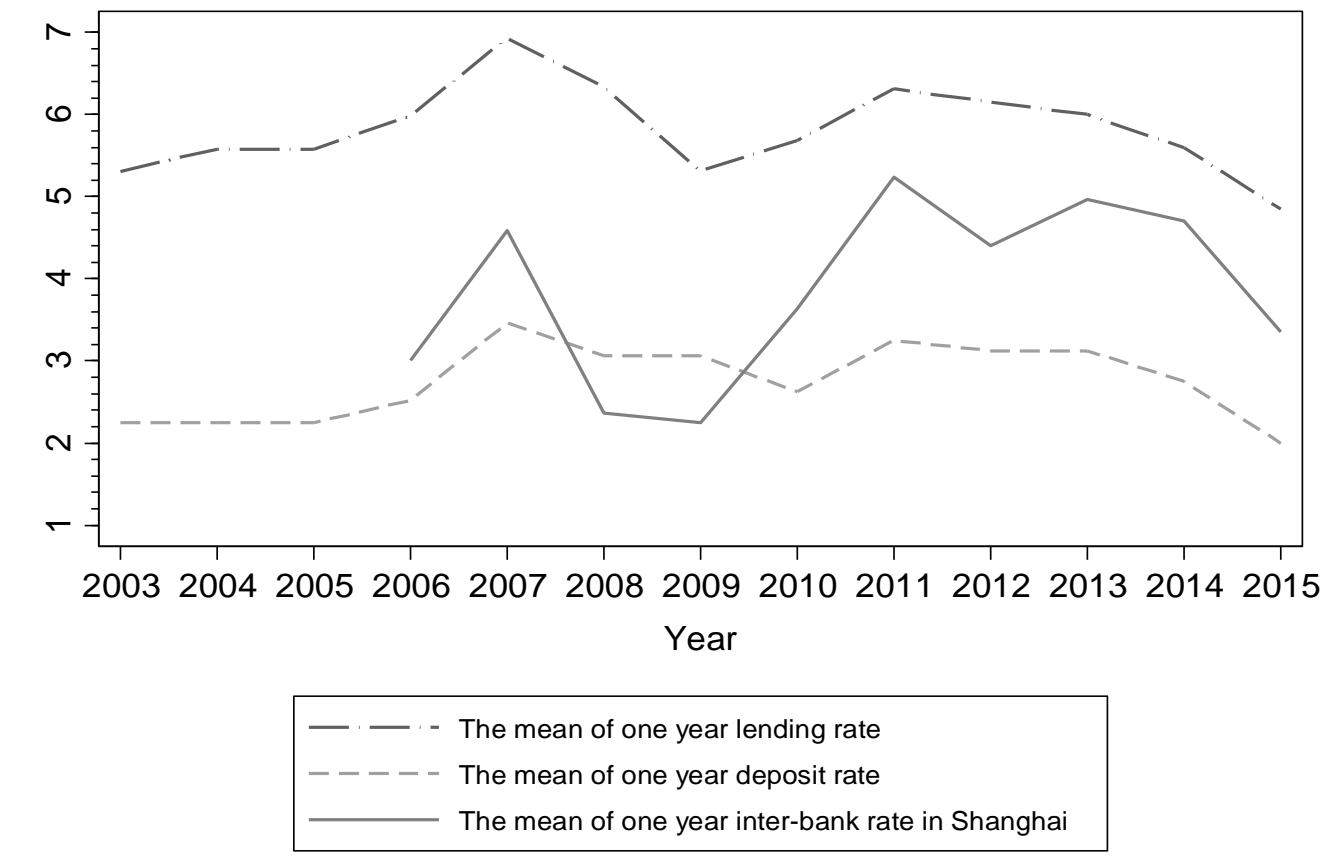

Data source: CSMAR Database

\section{Literature review and hypotheses development}

\subsection{Earnings transparency and debt financing}

The modern theory of capital structure began with the capital structure theories (Modigliani and Miller, 1958) and has been further developed by subsequent contributions, such as tradeoff theory and pecking order theory. Apart from the heterogeneity of firm level characteristics (Booth et al., 2001), the degree of market development has also been found to have a strong 
impact on the homogeneity of corporate behavior in developed markets (Rajan and Zingales, 1995), while firms in developing countries are distinctive to each other. Furthermore, market imperfections, such as asymmetric information problem, cause capital rationing (Stiglitz and Weiss, 1981) and the information environment of firms, is heterogeneous and has a strong impact on the access to funding sources (Booth et al., 2001).

The importance of transparent financial disclosures lies in its role in reducing the cost of external finance and in easing financial constraints. Corporate financing choices are affected by information issues between the insiders and outside investors (e.g. Jensen and Meckling, 1976), and information asymmetry is positively associated with the cost of capital (e.g. Lambert et al., 2007). Goldstein et al (2019) find that in markets that are effective in aggregating private information, disclosure negatively affects price informativeness. Therefore, on one hand, informationally opaque borrowers usually face higher cost of external finance. One the other hand, transparency and disclosure policies can shape a firm's information environment in the presence of agency conflicts. A high quality accounting reporting has a decisive bearing on financing through improving the contracting process, enhancing the level of monitoring and mitigating the misevaluation problems of both managers and financial analysts (Zhang and Lu, 2007).

Banks lenders are not only concerned with the interests they receive on the loan, but also with the riskiness of the loan issued (Stiglitz and Weiss, 1981) and therefore, they require a high quality accounting reporting to assess the information about credit worthiness and profitability of borrowers. Meanwhile, firms, consistently making timely and informative disclosures, are perceived to have a lower likelihood of withholding adverse information in the assessment of banks, and will consequently be charged a lower risk premium in debt finance (Francis et al., 2004). Bova et al. (2018) find that when the SOE's social concerns are sufficiently important and when the market competitiveness is sufficiently low, the SOE 
commits to fully disclosing its private information. Otherwise, the SOE commits to withholding its private information. Therefore, firms with high earnings disclosure quality would enjoy a lower effective interest cost on loans. Moreover, borrowing is typically a repeated game, earnings transparency from the high quality accounting system can serve as an implicit contract and an input in the explicit contract between the firms and banks, which thereby restricting managers from incurring agency costs in the contractual mechanisms. Therefore, we hypothesize

H1: Earnings transparency of firms is positively associated with the level of debt finance.

Even though, $\boldsymbol{H} \mathbf{1}$ does not exclude the possibility that the cost of equity capital may also decrease due to the improvement of earnings transparency (Botosan, 1997). This is because, according to the optimal capital structure argument (e.g. Qian et al., 2009), publicly listed companies are inclined to adjust debt ratio towards an equilibrium level to minimize cost of capital and to maximize firm value. However, we consider this concern to be relatively less salient to our hypothesis on debt finance for three reasons. First, in a government-dominated financial system in China (Fan et al., 2008), public firms rely more heavily on bank loans than on equity finance (Firth et al., 2009), where equity finance is strictly regulated by government, earnings transparency plays a more important role in accessing bank loan than equity finance (Tian et al., 2015). Second, compared with equity holders, lenders face more severe information asymmetries. Third, we call for an empirical investigation on the effects of earnings transparency on leverage which would be helpful to fully understand whether the effect is more significant for loans or for equity finance. Finally, we hypothesize a linear effect of earnings transparency on debt finance for Chinese companies to reflect their low level of earnings transparency (Joseph and Wong, 2012) and limited access to debt finance (Huang and Song, 2006), especially for those small and private firms. This is important as it implies that the benefits of improving transparency are still greater than the costs and businesses have 
incentives to improve transparency and to obtain more debt finance. This does not, however, exclude the possibility of non-linear effects (inverted $U$ ) where the costs of improving transparency become greater than the benefits of doing so ${ }^{1}$.

\subsection{Interest rate deregulation, earnings transparency and debt financing}

Capital structure theories assume that the availability of incremental capital is determined by the characteristics of the firm and credit rationing may exist because of information asymmetries (Stiglitz and Weiss, 1981). The value of a company's debt will change as the external environment changes (Acharya and Gale, 2011). Therefore, according to the market timing hypothesis (Baker and Wurgler, 2002), supply side effect is important in determining capital structure and supporting evidence is available from surveys of corporate managers (Brau and Fawcett, 2006) and large sample studies (Alti, 2006).

In the process of market-oriented reform of interest rate, liberalization facilitates the progress of deregulation by central government or central bank and moving towards a market-oriented and competition-driven mechanism. Therefore, interest rate liberalization is an important way to diversify financial products where financial institutions have a wider scope to price their financial products (Feyzioğlu et al., 2009). In contrast, a rigid regulation of interest rates constrains market competition and discourages banks from serving informationally opaque and highly risky firms (e.g. Gelos and Werner, 2002) because of inflexibility to charge an appropriate rate. The removal of administrative control on interest rates enables commercial banks to customize their financial products and prices to fully reflect the risk-relevant information of the borrowers in a competition-driven and market oriented way. For example, after loan rate ceiling is removed, risker borrowers would be able to obtain more debt finance with risk-adjusted loan prices (Chen and Ma, 2018). Therefore, credit supply increases and

\footnotetext{
${ }^{1}$ In an additional test, we include squared earnings transparency and find the existence of such non-linear effects. The results are not reported but available from the authors on request.
} 
businesses have better accesses to debt finance. To price correctly on risk, banks depend heavily on information transparency and the costs of collecting information. More flexible interest rates should reflect the reductions in information acquisition costs of commercial banks. The rapid development of information technology has changed the costs of the financing businesses, and banks' pricing on deposits and lending is required to be in line with the changing costs. Relaxing current interest rate regulations in China enables banks to charge a market-determined risk premium on loans, which is consistent with the risk profile of their borrowers (Xu, 2007). Therefore, we hypothesize

H2: Interest rate deregulation would strengthen the expected favorable impacts of earnings transparency on debt financing.

\section{Data and Methodology}

\subsection{Data Collection}

We collect empirical data from two sources. All firm-level financial data and market data are obtained from the China Stock Market and Accounting Research Database (CSMAR), and the data of corporate ownership structure are collected from China Centre for Economic Research Database (CCER) which is developed by SinoFin Information Technology Company and Peking University. We exclude sample firms in finance industry and those with missing data. Based on Barth et al. (2013), we drop the samples with less than 10 observations a year in each industry and we winsorize variables at a $99 \%$ level to reduce the outlier effects.

Our empirical data cover the time period between 2003 and 2015 for two reasons. First, this is the period when Chinese government has started to put forward with interest rate reform. The PBoC was active in controlling the interest rates in accordance with the macro-economic conditions during this period and market interest rates, in particular, show a distinct two-track system which is composed of a regulated state rate and a market rate (Zhang et al., 2014). Second, our variable construction requires to trace back data for 5 years (see the next section 
for more details) and to make the empirical results more comparable, we restrict our samples to this period to minimize the effects of missing values. Hence, 13,793 firm-year observations during the period of 2003-2015 are used in the following empirical analysis.

\subsection{Dependent variables: Debt financing}

Based on Rajan and Zingales (1995), we use total debt ratio to measure the debt financing, Lev, which is defined as the ratio of the book value of the firm $i$ 's total liabilities to total assets.

\subsection{Independent variables}

\subsubsection{Earnings transparency measure (Trans)}

Following Barth et al. (2013), we measure earnings transparency by the explanatory power of the returns-earnings relation to capture the extent to which earnings and change in earnings, and information correlated with these changes. This is because "regardless of the source of variation in earnings transparency, higher (lower) transparency will result in higher (lower) explanatory power in the returns-earnings relation" (Barth et al., 2013, p.209). Specifically, Trans is constructed by using adjusted $\mathrm{R}^{2} \mathrm{~s}$ from a two-step estimation procedure to permit both intertemporal and cross-sectional variation. The estimations of adjusted $\mathrm{R}^{2} \mathrm{~s}$ are established based on the relation between earnings and changes in earnings deflated by price, and contemporaneous annual stock returns.

The first $\mathrm{R}^{2}$ is calculated as annual returns-earnings relations estimated over industry according to the industry-year regression Eq. (1),

$$
\operatorname{Ret}_{i, j, t}=\alpha_{0}+\alpha_{1} * \frac{E_{i, j, t}}{P_{i, j, t-1}}+\alpha_{2} * \frac{\Delta E_{i, j, t}}{P_{i, j, t-1}}+\varepsilon_{i, j, t}
$$

Where $\operatorname{Ret}_{i, j, t}$ is the annual return measured as beginning four months after the firm $i$ 's fiscal year $t$ ends in the industry $j . E_{i, j, t}$ represents the annual earnings per share, and $P_{i, j, t}$ is the opening share price of the year. $\triangle E_{i, j, t}$ is the change in earnings from year $t-1$ to year $t$. The 
coefficients in the model, $\alpha_{0}, \alpha_{1}$ and $\alpha_{2}$, are assumed to be the same for all firms within the same industry $j$ in year $t$. We estimate this model for 21 industries during 13 years $(t=2003, \ldots$, 2015), and generate separate industry components as $\operatorname{Trans}_{j, t}$.

In order to fully capture the differences across firms in the returns-earnings relation, we place observations from Eq. (1) into one of four portfolios $p(p=1, \ldots, 4)$ based on the magnitude of their associated residuals $\varepsilon_{i, j, t}$ from each annual regression for that industry. For example, the first portfolio is comprised of the quartile of observations from each annual industry regression with the most negative residuals. Then, we calculate the second $\mathrm{R}^{2}$ to construct Trans from the portfolio-year regression Eq. (2) which permits the industry-neutral component of earnings transparency to vary over time. This estimation procedure does not constrain the coefficients in Eq. (2) and $\beta_{0}, \beta_{1}$ and $\beta_{2}$ are to be the same for firms within industry $j$ in year $t$. Rather, it constrains firms within portfolio $p$ to have the same coefficients in year $t$. Finally, we obtain 52 industry-neutral components (13 years and 4 portfolios) as $\operatorname{Transin}_{p, t}$.

$$
\operatorname{Ret}_{i, p, t}=\beta_{0}+\beta_{1} * \frac{E_{i, p, t}}{P_{i, p, t-1}}+\beta_{2} * \frac{\Delta E_{i, p, t}}{P_{i, p, t-1}}+\varepsilon_{i, p, t}
$$

Therefore, we obtain our earnings transparency for firm $i$ in year $t$ by summing the $\mathrm{R}^{2} \mathrm{~S}$ pertaining to firm $i$ 's industry and industry-neutral returns-earnings regressions in year $t$, i.e. $\operatorname{Transi}_{j, t}$ and $\operatorname{Transin}_{p, t}$, where $j$ and $p$ denote industry and portfolio, respectively.

$$
\operatorname{Trans}_{i, t}=\operatorname{Transi}_{j, t}+\operatorname{Transin}_{p, t}
$$

\subsubsection{Interest rate deregulation (IRdereg)}

Following existing literature on the relation between institutional environment and economic behavior (e.g. Wang et al., 2011), we use a dummy variable to capture interest rate deregulation (IRdereg) which is equal to one if the sample observation is in the year of 2004, 2012 and 2013 
when the interest rate market-oriented reforms were pushed forward actively by government, and zero otherwise. For example, low interest rate ceiling was released in 2004 and the lower limit of interest rate was implemented in 2015 where market started to play a more important role than government in interest rate determination and capital allocation.

In a robustness test, we also use a continuous variable IRdereg2 to measure the degree of interest rate deregulation. IRdereg2 is defined as the difference between market SHIBOR rate and government-controlled benchmark one-year lending rate. The greater the value of the difference, the greater the interest rate liberalization is to be. We expect that in the process of interest rate reforms, firms would have better access to debt finance, and the effect of earnings transparency on the debt financing would be more significant.

\subsection{Other control variables}

We follow Huang and Song (2006) to consider firm-level control variables, such as firm size, Tobin's Q, ownership etc. The detailed definitions and their expected effects on debt finance are provided in Table 1.

Table 1 Control Variables Definitions

\begin{tabular}{|c|c|c|}
\hline Variable & Definition & Expectation \\
\hline$R O A$ & $\begin{array}{l}\text { Profitability }=\text { Net income/annual } \\
\text { average total assets }\end{array}$ & $\begin{array}{l}\text { The effect is uncertain. On one hand, the higher the } \\
\text { profitability, the easier for a firm to obtain loans. On } \\
\text { the other, it may also have a stronger incentives to } \\
\text { use internal finance with the existence of } \\
\text { information asymmetries. }\end{array}$ \\
\hline Size & $\begin{array}{l}\text { Firm size }=\text { Natural logarithm of book } \\
\text { value of total assets }\end{array}$ & $\begin{array}{l}\text { Firm size is positively related to the ability of a firm } \\
\text { to raise debt. }\end{array}$ \\
\hline$T q$ & $\begin{array}{l}\text { Tobin's } Q=\text { (Current stock market value } \\
+ \text { net assets value of per non-tradable } \\
\text { shares multiplied by the number of non- } \\
\text { tradable shares + total liabilities)/ book } \\
\text { value of total asset }\end{array}$ & $\begin{array}{l}\text { The effect is uncertain. On one hand, the greater the } \\
\text { growth potential, the more loans needed to finance } \\
\text { growth. On the other, with little growth potential, } \\
\text { firms may rely more on external finance because of } \\
\text { the diminished cash flow. }\end{array}$ \\
\hline First & $\begin{array}{l}\text { Ownership structure }=\text { The proportion of } \\
\text { the firm's largest shareholding }\end{array}$ & $\begin{array}{l}\text { The higher non-tradable shares, the easier it is for the } \\
\text { firm to access bank loans. }\end{array}$ \\
\hline Liquid & $\begin{array}{l}\text { liquidity }=(\text { Cash and cash equivalents }+ \\
\text { short-term assets }) / \text { book value of total } \\
\text { asset }\end{array}$ & $\begin{array}{l}\text { The more liquid the firm's assets are, the easier to get } \\
\text { a loan. }\end{array}$ \\
\hline Fixas & $\begin{array}{l}\text { Tangibility }=\text { The ratio of net fixed } \\
\text { assets to total assets }\end{array}$ & $\begin{array}{l}\text { Tangibility is positively related to the ability to raise } \\
\text { debt finance. }\end{array}$ \\
\hline ETR & $\begin{array}{l}\text { Effective tax rate }=\text { Income tax expenses } \\
\text { divided by EBIT }\end{array}$ & $\begin{array}{l}\text { Tax rate is negatively related to long term debt (Kane } \\
\text { et al., 1985). Firms subject to higher tax rate are } \\
\text { inclined to use short term debts. }\end{array}$ \\
\hline
\end{tabular}




\begin{tabular}{ll}
\hline \multirow{3}{*}{ Industry } & $\begin{array}{l}\text { Industry dummy variables which are } \\
\text { classified according to the CSRC (China } \\
\text { Securities Regulatory Commission) } \\
\text { classification standard issued in 1998 }\end{array}$ \\
\hline
\end{tabular}

\subsection{Summary Statistics}

Table 2 presents the descriptive statistics for the variables used in the following estimations. In terms of earnings transparency (Trans), China's listed firms averagely have a lower earnings transparency than their US counterparts (Barth et al., 2013). In particular, the mean and median of earnings transparency (Trans) are 0.204 and 0.169 respectively, while the mean and median of the earnings transparency in industries is 0.065 and 0.035 . It shows that, the mean and median of total debt ratio (Lev) is 0.510 and 0.510 in China, which is in consistent with Shen et al. (2009).

Table 2 Descriptive statistics

\begin{tabular}{lllllll}
\hline Variable & Obs & Mean & Median & Std. dev. & Min & Max \\
\hline Trans & 13793 & 0.204 & 0.169 & 0.152 & -0.014 & 0.734 \\
Transi & 13793 & 0.065 & 0.035 & 0.100 & -0.05 & 0.618 \\
Transin & 13793 & 0.140 & 0.109 & 0.106 & 0.007 & 0.374 \\
Lev & 13793 & 0.510 & 0.510 & 0.238 & 0.059 & 1.533 \\
IRdereg & 13793 & 0.307 & 0.000 & 0.461 & 0.000 & 1.000 \\
ROA & 13793 & 0.031 & 0.033 & 0.078 & -0.324 & 0.232 \\
Size & 13793 & 21.722 & 21.602 & 1.247 & 18.868 & 25.400 \\
Tq & 13793 & 2.316 & 1.925 & 1.274 & 0.954 & 9.259 \\
First & 13793 & 36.282 & 34.110 & 15.495 & 8.810 & 75.000 \\
Liquid & 13793 & 0.169 & 0.136 & 0.126 & 0.005 & 0.617 \\
Fixas & 13793 & 0.269 & 0.236 & 0.183 & 0.002 & 0.763 \\
ETR & 13793 & 0.189 & 0.166 & 0.156 & 0.000 & 0.857 \\
State & 13793 & 0.534 & 1.000 & 0.499 & 0.000 & 1.000 \\
\hline
\end{tabular}

The table reports summary statistics for all samples used in this study, including dependent, independent and control variables between 2003 and 2015.

In addition, to investigate the bias that comes from high correlation among independent variables in the regression, Table 3 reports the continuous correlations (lower section) and partial correlations (upper section) of each variable and shows that the debt financing behavior is positive correlated with earnings transparency and with interest rate deregulation, consistent with $\mathrm{H} 1$ and $\mathrm{H} 2$. 
Table 3 Correlation matrix of key variables

\begin{tabular}{|c|c|c|c|c|c|c|c|c|c|c|c|}
\hline & Trans & Lev & IRdereg & ROA & Size & $\mathrm{Tq}$ & First & Liquid & Fixas & Etr & State \\
\hline Trans & 1.00 & $0.03^{* * * *}$ & $-0.11^{* * * *}$ & -0.01 & $0.02^{* *}$ & $-0.19^{* * *}$ & $0.05^{* * * *}$ & $-0.03^{* * *}$ & 0.01 & $0.05^{* * *}$ & $0.13^{* * *}$ \\
\hline Lev & $0.03^{* *}$ & 1.00 & $0.13^{* * * *}$ & $-0.39^{* * *}$ & $0.24^{* * * *}$ & $0.13^{* * * *}$ & 0.00 & $-0.35^{* * *}$ & $0.03^{* * * *}$ & 0.02 & $0.15^{\text {*** }}$ \\
\hline IRdereg & $0.12^{* * * *}$ & $0.14^{* * * *}$ & 1.00 & -0.01 & $-0.12^{* * * *}$ & $0.12^{* * *}$ & 0.01 & $-0.10^{* * *}$ & $0.12^{* * * *}$ & -0.01 & $0.30^{* * *}$ \\
\hline ROA & -0.01 & $-0.52^{* * *}$ & $0.04^{* * *}$ & 1.00 & $0.20^{* * * *}$ & 0.01 & $0.15^{* * * *}$ & $0.29^{* * * *}$ & $-0.12^{* * *}$ & $0.24^{* * *}$ & $-0.05^{* * *}$ \\
\hline Size & $0.02^{* *}$ & 0.01 & $0.13^{* * *}$ & $0.27^{* * * *}$ & 1.00 & $-0.33^{* * * *}$ & $0.27^{* * * *}$ & $-0.04^{* * * *}$ & $0.03^{* * * *}$ & $0.20^{* * * *}$ & $0.23^{\text {*** }}$ \\
\hline $\mathrm{Tq}$ & $-0.14^{* * * *}$ & $0.33^{* * * *}$ & $-0.08^{* * * *}$ & $-0.22^{* * *}$ & $-0.42^{* * *}$ & 1.00 & $-0.22^{* * *}$ & $0.03^{* *}$ & $-0.09^{* * *}$ & $-0.15^{\text {*** }}$ & $-0.10^{* * * *}$ \\
\hline First & $0.05^{* * * *}$ & $-0.05^{* * *}$ & -0.01 & $0.16^{* * *}$ & $0.30^{* * *}$ & $-0.20^{* * *}$ & 1.00 & -0.01 & $0.06^{* * * *}$ & $0.08^{* * * *}$ & $0.23^{* * *}$ \\
\hline Liquid & $-0.03^{* * *}$ & $-0.32^{* * *}$ & $0.11^{* * *}$ & $0.23^{* * * *}$ & $-0.09^{* * * *}$ & $0.07^{* * * *}$ & $-0.02^{*}$ & 1.00 & $-0.35^{\text {**** }}$ & $0.06^{* * * *}$ & $-0.10^{* * * *}$ \\
\hline Fixas & -0.00 & $0.05^{* * *}$ & $-0.12^{\text {**** }}$ & $-0.10^{* * *}$ & $0.07^{* * * *}$ & $-0.09^{* * *}$ & $0.06^{* * *}$ & $-0.36^{* * *}$ & 1.00 & $-0.06^{\text {**** }}$ & $0.18^{\text {*** }}$ \\
\hline ETR & $0.04^{* * * *}$ & $-0.04^{* * *}$ & 0.01 & $0.19^{* * * *}$ & $0.13^{* * *}$ & $-0.15^{* * *}$ & $0.04^{* * * *}$ & -0.00 & $-0.04^{* * *}$ & 1.00 & $0.05^{* * *}$ \\
\hline State & $0.11^{* * * *}$ & $0.06^{* * *}$ & $-0.30^{* * *}$ & -0.01 & $0.23^{* * *}$ & $-0.12^{* * *}$ & $0.22^{* * * *}$ & $-0.12^{* * *}$ & $0.19^{* * * *}$ & $0.04^{* * * *}$ & 1.00 \\
\hline
\end{tabular}

The table reports the continuous correlations (lower section) and partial correlations (upper section) of each variable. $*, * *$ and $* * *$ denote statistical significance at $10 \%, 5 \%$ and $1 \%$ level for which the null hypothesis is rejected. 


\section{Results and Discussion}

\subsection{Baseline specifications}

\subsubsection{The effect of earnings transparency}

The main objective of this paper is to investigate the impacts of earnings transparency on corporate debt finance by controlling for the interaction with interest rate regulation. We start with the model Eq. (4) to examine the relationship between earnings transparency and firms' leverage decisions to test $\boldsymbol{H} \boldsymbol{1}$.

$$
\begin{array}{r}
\text { Lev }_{i, t}=\beta_{0}+\beta_{1} \text { Trans }_{i, t}+\beta_{2} \text { ROA }_{i, t}+\beta_{3} \text { Size }_{i, t}+\beta_{4} \text { Tq }_{i, t}+\beta_{5} \text { First }_{i, t}+ \\
\beta_{6} \text { Liquid }_{i, t}+\beta_{7} \text { Fixas }_{i, t}+\beta_{8} \text { ETR }_{i, t}+\varepsilon_{i, t} \ldots \ldots \ldots \ldots \ldots \ldots
\end{array}
$$

Next, Eq. (5) is designed to test $\boldsymbol{H} \mathbf{2}$ by adding the variable interest rate deregulation $\left(\right.$ IRdereg $\left._{i, t}\right)$ and earning transparency $\left(\operatorname{Trans}_{i, t}\right)$, as well as the interaction between them. As the variable IRdere $g_{i, t}$ is measured as a dummy variable, we exclude the year dummies in our baseline and subsequent specifications.

$$
\begin{array}{r}
\text { Lev }_{i, t}=\beta_{0}+\beta_{1} \text { Trans }_{i, t}+\beta_{2} \text { IRdereg }_{i, t}+\beta_{3} \text { IRdereg }_{i, t} * \text { Trans }_{i, t}+ \\
\beta_{4} \text { ROA }_{i, t}+\beta_{5} \text { Size }_{i, t}+\beta_{6} \text { Tq }_{i, t}+\beta_{7} \text { First }_{i, t}+\beta_{8} \text { Liquid }_{i, t}+ \\
\beta_{9} \text { Fixas }_{i, t}+\beta_{10} \text { ETR }_{i, t}+\varepsilon_{i, t} \ldots \ldots \ldots \ldots \ldots \ldots \ldots \ldots \ldots \ldots \ldots \ldots \ldots \ldots
\end{array}
$$

We follow Petersen (2009) and employ the cluster analysis at a firm level with the control of industry. Tables 4 and 5 show the baseline results of Eq. (4) and (5) respectively. Table 4 shows that total debt ratio (Lev) increases over earnings transparency (Trans, Transi and Transin) at a $1 \%$ significance level, supporting $\boldsymbol{H} \mathbf{1}$ that the degree of earnings transparency of Chinese listed firms is positively related with their debt financing behavior. We also investigate the possible multicollinearity problem by Variance Inflation Factors (VIF). Our results show little evidence of such a problem with all VIF less than 10 and an average of 1.78. Besides, the constant terms are significant in most specifications. This result indicates that the enterprise 
itself will have a expect target debt ratio. We also find the goal of capital structure, which is the logic starting point of studying the capital structure, to be significant.

Table 4. The effect of earnings transparency on corporate debt financing

\begin{tabular}{|c|c|c|c|}
\hline & $\begin{array}{l}(1) \\
\text { Lev }\end{array}$ & $\begin{array}{l}(2) \\
\text { Lev }\end{array}$ & $\begin{array}{l}(3) \\
\text { Lev }\end{array}$ \\
\hline Constant & $\begin{array}{c}-0.859 * * * \\
(-13.50)\end{array}$ & $\begin{array}{c}-0.850 * * * \\
(-13.42)\end{array}$ & $\begin{array}{c}-0.850 * * * \\
(-13.38)\end{array}$ \\
\hline Trans & $\begin{array}{c}0.051^{* * * *} \\
(6.20)\end{array}$ & & \\
\hline Transi & & $\begin{array}{c}0.070 * * * \\
(6.01)\end{array}$ & \\
\hline Transin & & & $\begin{array}{c}0.044 * * * \\
(3.70)\end{array}$ \\
\hline ROA & $\begin{array}{c}-1.424 * * * \\
(-28.92)\end{array}$ & $\begin{array}{c}-1.426 * * * \\
(-28.92)\end{array}$ & $\begin{array}{c}-1.425 * * * \\
(-28.87)\end{array}$ \\
\hline Size & $\begin{array}{c}0.063 * * * \\
(23.45)\end{array}$ & $\begin{array}{c}0.063 * * * \\
(23.45)\end{array}$ & $\begin{array}{c}0.063 * * * \\
(23.37)\end{array}$ \\
\hline First & $\begin{array}{l}0.000 \\
(0.66)\end{array}$ & $\begin{array}{l}0.000 \\
(0.70)\end{array}$ & $\begin{array}{l}0.000 \\
(0.68)\end{array}$ \\
\hline $\mathrm{Tq}$ & $\begin{array}{c}0.047 * * * \\
(11.42)\end{array}$ & $\begin{array}{c}0.047 * * * \\
(11.40)\end{array}$ & $\begin{array}{c}0.047 * * * \\
(11.34)\end{array}$ \\
\hline Liquid & $\begin{array}{c}-0.438 * * * \\
(-15.27)\end{array}$ & $\begin{array}{c}-0.437 * * * \\
(-15.26)\end{array}$ & $\begin{array}{c}-0.438 * * * \\
(-15.27)\end{array}$ \\
\hline Fixas & $\begin{array}{l}-0.035 \\
(-1.53)\end{array}$ & $\begin{array}{l}-0.036 \\
(-1.54)\end{array}$ & $\begin{array}{l}-0.035 \\
(-1.52)\end{array}$ \\
\hline ETR & $\begin{array}{l}0.078 * * * \\
(5.29)\end{array}$ & $\begin{array}{c}0.079 * * * \\
(5.38)\end{array}$ & $\begin{array}{l}0.078 * * * \\
(5.26)\end{array}$ \\
\hline Year dummies & Control & Control & Control \\
\hline Industry dummies & Control & Control & Control \\
\hline $\begin{array}{l}\text { Observations } \\
\text { Adjusted R-squared }\end{array}$ & $\begin{array}{l}13793 \\
0.449\end{array}$ & $\begin{array}{l}13793 \\
0.448\end{array}$ & $\begin{array}{c}13793 \\
0.448\end{array}$ \\
\hline
\end{tabular}

Note1: The table presents regression coefficients and t-statistics (in parentheses) for Eq. (4), by using a cluster analysis at firm level for all samples with a full set of controls. The dependent variables are the total debt ratio. All VIFs are lower than 10.

Note 2: *** and *** denote statistical significance at $10 \%, 5 \%$ and $1 \%$ level for which the null hypothesis is rejected.

\subsubsection{Interest rate deregulation, earnings transparency and corporate debt financing}

Furthermore, Table 5 shows that interest rate deregulation (IRdereg) is significantly and negatively related to the total debt ratio $(L e v)$ at a $1 \%$ level. This result implies that the action of the interest rate deregulation brings more uncertainty of financing so that firms may reduce debt financing in the same year. The results are consistent with Li et al. (2018) and Wang et al. (2018). The estimate of interaction term (IRdereg*Trans) is positive and indicates that the effect of earnings transparency on firms' leverage increases along with a process of constant 
deregulation on interest rate, supporting $\boldsymbol{H} \mathbf{2}$, where with the improvement of earnings transparency, firms use more debt finance compared with equity finance.

Table 5. Interest rate deregulation, earnings transparency and corporate debt financing

\begin{tabular}{lccc}
\hline & $(1)$ & $(2)$ & $(3)$ \\
& Lev & Lev & Lev \\
\hline Constant & $-0.893^{* * *}$ & $-0.894 * * *$ & $-0.886^{* * * *}$ \\
& $(-14.02)$ & $(-14.10)$ & $(-13.93)$ \\
IRdereg & $-0.075^{* * *}$ & $-0.071^{* * *}$ & $-0.076^{* * *}$ \\
& $(-14.80)$ & $(-16.52)$ & $(-14.78)$ \\
Trans & 0.011 & & \\
Transi & $(1.07)$ & $0.029 * *$ & \\
& & $(2.38)$ & -0.013 \\
Transin & & & $(-0.80)$ \\
& & & \\
IRdereg *Trans & $0.059^{* * *}$ & & \\
& $(3.63)$ & $0.120^{* * *}$ & \\
IRdereg *Transi & & $(2.61)$ & $(3.72)$ \\
& & & Yes \\
IRdereg *Transin & & & Yes \\
Control variables & Yes & Yes & 13793 \\
Industry dummies & Yes & 13793 & 0.464 \\
\hline Observations & 13793 & 0.464 & \\
Adjusted R-squared & 0.464 & & \\
\hline
\end{tabular}

Note 1: The table presents regression coefficients and t-statistics (in parentheses) for Eq. (5), by using a cluster analysis at the firm level for all samples with full set of controls. The dependent variables are the total debt ratio. We exclude the year dummies because the variable IRdereg is measured as a year dummy variable.

Note 2: All VIFs are lower than 10. *,** and *** denote statistical significance at $10 \%, 5 \%$ and $1 \%$ level for which the null hypothesis is rejected. Results for control variables are not reported but available upon request from the authors.

\subsection{Mechanisms}

\subsubsection{Earnings transparency and cost of debt financing}

Our early results suggest that earnings transparency increases corporate leverage and in this section, we follow Barth at al. (2013) to examine the mechanism from the costing perspective where earnings transparency reduces cost of debt finance and then motivates companies to raise more debt. To capture the impacts of interest rate deregulation on capital structure, we use regulated interest as dependent variables to measure the difference between market SHIBOR rates and the actual interest rates of samples. 
We apply a cluster analysis at firm level for all samples with a full set of control variables and report the results in Table 6. It shows that the effects of earnings transparency on the cost of debt finance is negative and statistically significant at a $1 \%$ level. Therefore, our empirical results support the conjecture that earnings transparency improves leverage by reducing the cost of debt finance.

Table 6. Earnings transparency and the cost of debt financing

\begin{tabular}{lccc}
\hline & $(1)$ & $(2)$ & $(3)$ \\
& Cost of debt finance & Cost of debt finance & Cost of debt finance \\
\hline Constant & -4.738 & $-5.932^{*}$ & -4.007 \\
Trans & $(-1.43)$ & $(-1.75)$ & $(-1.20)$ \\
& $-3.352^{* * *}$ & & \\
Transi & $(-4.22)$ & & \\
& & $-1.629 *$ & \\
Transin & & $(-1.76)$ & $-4.534 * * *$ \\
& & & $(-3.99)$ \\
Control variables & & & Yes \\
Industry dummies & Yes & & Yes \\
Year dummies & Yes & & Yes \\
\hline Observations & 651 & 651 & 651 \\
Adjusted R-squared & 0.46 & 0.441 & 0.461 \\
\hline
\end{tabular}

Note 1: The table presents regression coefficients and t-statistics (in parentheses) for tests of earnings transparency and the cost of debt financing by using a cluster analysis at the firm level for all samples with full set of controls. The dependent variables are Regulated Interest, which is calculated by the difference between market SHIBOR rates and the actual ratio of the business loan of firms from commercial bank.

Note 2: All VIFs are lower than $10 . *, * *$ and $* * *$ denote statistical significance at $10 \%, 5 \%$ and $1 \%$ level for which the null hypothesis is rejected. Results for control variables are not reported but available upon request from the authors.

\subsubsection{Earnings transparency, interest rate deregulation and cost of debt financing}

We explicitly consider the impacts of interest rate deregulation by IRdereg and its interaction terms with earnings transparency measures. Similar to earlier results, interest rate deregulation reduces leverage by increasing cost of debt, just as in table 7 . The coefficients of interaction terms, however, are statistically negative, support $\mathbf{H 2}$, where interest rate deregulation enhances the favorable effects of earnings transparency on corporate debt financing by reducing the costs of debt. 
Table 7. Earnings transparency, interest rate deregulation and cost of debt finance

\begin{tabular}{|c|c|c|c|}
\hline & $(1)$ & $(2)$ & $(3)$ \\
\hline & Cost of debt finance & Cost of debt finance & Cost of debt finance \\
\hline \multirow[t]{2}{*}{ Constant } & $-7.573 * *$ & $-7.946 * *$ & $-8.396 * *$ \\
\hline & $(-2.16)$ & $(-2.21)$ & $(-2.44)$ \\
\hline \multirow[t]{2}{*}{ IRdereg } & $1.554 * * *$ & 0.255 & $2.299 * * *$ \\
\hline & -3.71 & -0.7 & -6.17 \\
\hline \multirow[t]{2}{*}{ Trans } & 0.671 & & \\
\hline & $(0.71)$ & & \\
\hline \multirow[t]{2}{*}{ Transi } & & -1.354 & \\
\hline & & $(-1.26)$ & \\
\hline \multirow[t]{2}{*}{ Transin } & & & $7.890 * * *$ \\
\hline & & & $(4.94)$ \\
\hline \multirow[t]{2}{*}{ IRdereg *Trans } & $-5.617 * * *$ & & \\
\hline & $(-3.71)$ & & \\
\hline \multirow[t]{2}{*}{ IRdereg *Transi } & & 4.352 & \\
\hline & & (1.11) & \\
\hline \multirow[t]{2}{*}{ IRdereg *Transin } & & & $-13.442 * * *$ \\
\hline & & & $(-6.84)$ \\
\hline Control variables & Yes & & Yes \\
\hline Industry dummies & Yes & & Yes \\
\hline Year dummies & Yes & & Yes \\
\hline Observations & 651 & 651 & 651 \\
\hline Adjusted R-squared & 0.385 & 0.361 & 0.418 \\
\hline
\end{tabular}

Note 1: The table presents regression coefficients and t-statistics (in parentheses) for tests of earnings transparency, interest rate deregulation and the cost of debt financing by using a cluster analysis at the firm level for all samples with full set of controls. The dependent variables is regulated Interest, which is calculated by the difference between market SHIBOR rates and the actual ratio of the business loan of firms from commercial bank.

Note 2: All VIFs are lower than 10.*,** and $* * *$ denote statistical significance at $10 \%, 5 \%$ and $1 \%$ level for which the null hypothesis is rejected. Results for control variables are not reported but available upon request from the authors.

\subsection{The impact of corporate ownership in China}

Existing capital structure literature has highlighted the effects of ownership structure on corporate capital structure decisions (e.g. Berger et al., 1997) and shown that state-owned enterprises (SOEs) in China have easier access to credit and gain political advantages than private firms (Brandt and $\mathrm{Li}, 2003$ ). Firth et al. (2009) also suggest that having the state as a minority owner would help private firms obtain bank loans easily, especially for firms located in a less developed banking sector. The economic transition that China is experiencing is characterized by the transformation of the financial system from a relation and bank-dominated 
system, to an arm's-length security market dominated system. Therefore, it is important to investigate corporate capital structure under this scenario within a regulated banking market in China.

This interest-sharing relationship between SOEs and state-owned banks encourages Chinese banking system to stipulate preference loan rates and lend primarily to SOEs with little regard for commercial motives (Liu et al. 2011), known as ‘ownership discrimination’ in banking finance. Secondly, government usually supports SOEs that are in financial distress through direct investment, loans, or reduced taxes, and also writes off prior loans or changes the terms of prior loans because of the political objectives such as employment goals. These 'soft budget constraints' are commonly seen in transition and socialist economies (Frydman et al., 1999). As SOEs, local governments and their investment vehicles remain as large borrowers in Chinese credit markets, and therefore, it is reasonable to expect that they tend to be less sensitive and less responsive to market interest rates, partially marginalizing the potential benefits of allocating capital more efficiently via market-based interest rates. Hence, we examine the effect of state ownership on corporate leverage by interacting earnings transparency and interest rate control as:

$$
\begin{aligned}
& \text { Lev }_{i, t}=\beta_{0}+\beta_{1} \text { Trans }_{i, t}+\beta_{2} \text { IRdereg }_{i, t}+\beta_{3} \text { State }_{i, t}+\beta_{4} \text { State }_{i, t} * \text { Trans }_{i, t}+\beta_{5} \text { IRdereg }_{i, t} * \\
& \text { Trans }_{i, t}+\beta_{6} \text { State }_{i, t} * \text { IRdereg }_{i, t}+\beta_{7} \text { State }_{i, t} * \text { IRdereg }_{i, t} * \text { Trans }_{i, t}+\beta_{8} \text { ROA }_{i, t}+\beta_{9} \text { Size }_{i, t}+ \\
& \beta_{10} T q_{i, t}+\beta_{11} \text { First }_{i, t}+\beta_{12} \text { Liquid }_{i, t}+\beta_{13} \text { Fixas }_{i, t}+\beta_{14} \text { ETR }_{i, t}+\varepsilon_{i, t}
\end{aligned}
$$

Where State $_{i, t}$ is a dummy variable indicating the nature of a firm's ownership, which equals to one if the firm is a SOE, zero otherwise.

Table 8 presents the results of Eq. (6) and shows that the coefficient estimates of the interaction term State*IRdereg*Trans is significantly negative, indicating that the favorable effects of earnings transparency on corporate debt financing is weakened when considering the corporate ownership effects. It implies that, in China, SOEs under the condition of deregulating 
interest rate still have an advantage to acquire debt finances because of the existing natural benefits between SOEs and state-owned banks (Rao and Jiang, 2013). Such an advantage enables SOEs to have a better access to bank finance.

Table 8. Corporate ownership, interest rate deregulation and debt financing

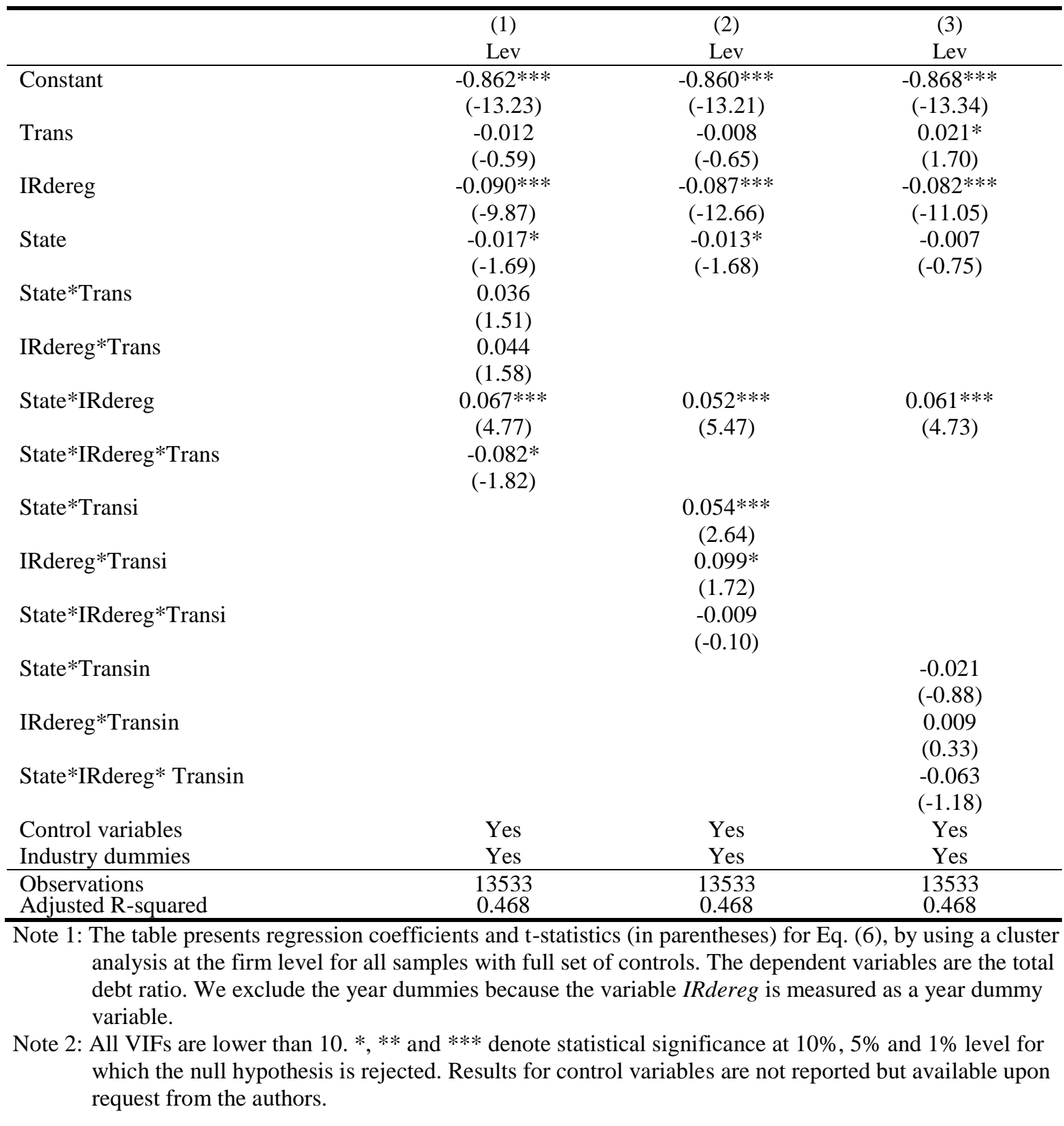

\subsection{The impact of economic growth target in each province of China}

$\mathrm{Xu}$ and Liang (2014) suggested that the government can promote regional economic development through strategic adjustment of economic growth targets. Further more, $\mathrm{Xu}$ and 
Liu (2017) suggested that setting an economic growth target is a worldwide phenomenon ignored by current studies. Therefore, we use the economic growth target to test the impact of interest rate deregulation and earnings transparency on debt financing in different economic growth target in different province of China.

Table 9. Economic growth target, interest rate deregulation and debt financing

\begin{tabular}{|c|c|c|c|}
\hline & $\begin{array}{l}(1) \\
\text { Lev }\end{array}$ & $\begin{array}{l}(2) \\
\text { Lev }\end{array}$ & $\begin{array}{l}(3) \\
\text { Lev }\end{array}$ \\
\hline Constant & $\begin{array}{c}-1.046 * * * \\
(-12.42)\end{array}$ & $\begin{array}{c}-1.058 * * * \\
(-14.37)\end{array}$ & $\begin{array}{c}-1.079 * * * \\
(-14.62)\end{array}$ \\
\hline Trans & $\begin{array}{l}-0.071 \\
(-0.67)\end{array}$ & $\begin{array}{l}-0.008 \\
(-0.60)\end{array}$ & $\begin{array}{c}0.085 * * * \\
(5.63)\end{array}$ \\
\hline IRdereg & $\begin{array}{l}-0.079 \\
(-1.58)\end{array}$ & $\begin{array}{l}-0.036 \\
(-1.08)\end{array}$ & $\begin{array}{c}-0.066 * * \\
(-2.07)\end{array}$ \\
\hline Target & $\begin{array}{l}0.006 \\
(1.22)\end{array}$ & $\begin{array}{c}0.007 * * \\
(2.35)\end{array}$ & $\begin{array}{c}0.010 * * * \\
(3.02)\end{array}$ \\
\hline Target*Trans & $\begin{array}{l}0.010 \\
(0.94)\end{array}$ & & \\
\hline IRdereg*Trans & $\begin{array}{l}0.108 \\
(0.75)\end{array}$ & & \\
\hline Target*IRdereg & $\begin{array}{l}0.000 \\
(0.07)\end{array}$ & $\begin{array}{l}-0.004 \\
(-1.24)\end{array}$ & $\begin{array}{l}-0.001 \\
(-0.25)\end{array}$ \\
\hline Target*IRdereg*Trans & $\begin{array}{l}-0.007 \\
(-0.45)\end{array}$ & & \\
\hline Target*Transi & & $\begin{array}{c}0.008 * * * \\
(3.82)\end{array}$ & \\
\hline IRdereg*Transi & & $\begin{array}{l}-0.475 \\
(-1.57)\end{array}$ & \\
\hline Target*IRdereg*Transi & & $\begin{array}{c}0.068 * * \\
(2.21)\end{array}$ & \\
\hline Target*Transin & & & $\begin{array}{c}-0.011 * * * \\
(-4.66)\end{array}$ \\
\hline IRdereg*Transin & & & $\begin{array}{l}0.072 \\
(0.73)\end{array}$ \\
\hline Target*IRdereg* Transin & & & $\begin{array}{l}-0.002 \\
(-0.16)\end{array}$ \\
\hline Control variables & Yes & Yes & Yes \\
\hline Industry dummies & Yes & Yes & Yes \\
\hline Observations & 12727 & 12727 & 12727 \\
\hline Adjusted R-squared & 0.436 & 0.437 & 0.437 \\
\hline
\end{tabular}

Note 1: The table presents regression coefficients and t-statistics (in parentheses) for Eq. (7), by using a cluster analysis at the firm level for all samples with full set of controls. The dependent variables are the total debt ratio. We exclude the year dummies because the variable IRdereg is measured as a year dummy variable.

Note 2: All VIFs are lower than 10. *,** and *** denote statistical significance at $10 \%, 5 \%$ and $1 \%$ level for which the null hypothesis is rejected. Results for control variables are not reported but available upon request from the authors. 
Table 9 presents the results and shows that the coefficient estimates of the interaction term Target*IRdereg*Transi is significantly positive in column (2), indicating that the favorable effects of industry-specific earnings transparency on corporate debt financing is strengthened when considering the economic growth target in different province of China. It implies that economic growth target under the condition of deregulating interest rate the government's economic regulation is beneficial to the entire industry, not a single enterprise. That means government control is conducive to enhancing the transparency of the industry that is firm's own, not firm's own transparency.

\subsection{The impact of marketization index in each province of China}

To measure distortion, Zhang et al. (2018) used the Marketization Index which is published by the China National Economic Research Institute. They suggested that the Marketization Index have a positive effect on TFP in the early stages of development. As such, we use the Marketization Index to test the impact of interest rate deregulation and earnings transparency on debt financing in different marketization level in different province of China.

Table 10 presents the results and shows that the coefficient estimates of the interaction term Marketization*IRdereg*Transin is significantly positive, indicating that the favorable effects of company-specific earnings transparency on corporate debt financing is strengthened when considering the marketization level in different province of China. Specifically, this result shows that marketization under the condition of deregulating interest rate still has an advantage to acquire debt financing because of the existing marketization reform dividend. As such, investors would find it worth to pay more attention to the company's own unique information transparency in the provinces with high degree of marketization. 
Table 10. Marketization index, interest rate deregulation and debt financing

\begin{tabular}{|c|c|c|c|}
\hline & $\begin{array}{l}(1) \\
\text { Lev }\end{array}$ & $\begin{array}{l}(2) \\
\text { Lev }\end{array}$ & $\begin{array}{c}(3) \\
\text { Lev }\end{array}$ \\
\hline Constant & $\begin{array}{c}-0.993 * * * \\
(-14.76)\end{array}$ & $\begin{array}{c}-0.970 * * * \\
(-14.64)\end{array}$ & $\begin{array}{c}-0.988 * * * \\
(-14.92)\end{array}$ \\
\hline Trans & $\begin{array}{c}0.112 * * \\
(2.24)\end{array}$ & $\begin{array}{l}-0.000 \\
(-0.01)\end{array}$ & $\begin{array}{c}0.094 * * * \\
(6.36)\end{array}$ \\
\hline IRdereg & $\begin{array}{l}-0.016 \\
(-0.65)\end{array}$ & $\begin{array}{c}-0.063 * * * \\
(-2.81)\end{array}$ & $\begin{array}{l}-0.004 \\
(-0.18)\end{array}$ \\
\hline Marketization & $\begin{array}{l}0.002 \\
(0.96)\end{array}$ & $\begin{array}{l}-0.000 \\
(-0.16)\end{array}$ & $\begin{array}{l}0.003 \\
(1.23)\end{array}$ \\
\hline Marketization*Trans & $\begin{array}{l}-0.011 \\
(-1.62)\end{array}$ & & \\
\hline IRdereg*Trans & $\begin{array}{l}-0.071 \\
(-0.79)\end{array}$ & & \\
\hline Marketization*IRdereg & $\begin{array}{c}-0.008 * * \\
(-2.54)\end{array}$ & $\begin{array}{l}-0.002 \\
(-0.78)\end{array}$ & $\begin{array}{c}-0.010 * * * \\
(-3.69)\end{array}$ \\
\hline Marketization*IRdereg*Trans & $\begin{array}{l}0.015 \\
(1.34)\end{array}$ & & \\
\hline Marketization*Transi & & $\begin{array}{c}0.009 * * * \\
(3.46)\end{array}$ & \\
\hline IRdereg*Transi & & $\begin{array}{c}0.621 * * \\
(2.17)\end{array}$ & \\
\hline Marketization*IRdereg*Transi & & $\begin{array}{l}-0.057 \\
(-1.60)\end{array}$ & \\
\hline Marketization*Transin & & & $\begin{array}{c}-0.016 * * * \\
(-5.19)\end{array}$ \\
\hline IRdereg*Transin & & & $\begin{array}{c}-0.179 * * \\
(-2.14)\end{array}$ \\
\hline Marketization*IRdereg* Transin & & & $\begin{array}{c}0.033 * * * \\
(3.03)\end{array}$ \\
\hline Control variables & Yes & Yes & Yes \\
\hline Industry dummies & Yes & Yes & Yes \\
\hline Observations & 12749 & 12749 & 12749 \\
\hline Adjusted R-squared & 0.435 & 0.436 & 0.436 \\
\hline
\end{tabular}

Note 1: The table presents regression coefficients and t-statistics (in parentheses) for Eq. (7), by using a cluster analysis at the firm level for all samples with full set of controls. The dependent variables are the total debt ratio. We exclude the year dummies because the variable IRdereg is measured as a year dummy variable.

Note 2: All VIFs are lower than $10 . * * *$ and $* * *$ denote statistical significance at $10 \%, 5 \%$ and $1 \%$ level for which the null hypothesis is rejected. Results for control variables are not reported but available upon request from the authors.

\subsection{Endogeneity tests}

The robustness of above results could be also subjective to the endogeneity issue which may exist because of the reverse causality where firms have higher debt ratio might be more likely to be supervised by lenders, and then have higher information transparency. The second reason 
of endogeneity is that better firms (e.g. corporate governance) have more debt ratio and higher information transparency. To address this issue, we use a variety of empirical models, such as fixed effect model, fixed effect model with instrument variables (IV), two-period factors regression method with IV and the instrumental variables used are earnings management index (Prawitt et al., 2009) and lagged Trans. Table 11 shows the results where endogeneity issue does not exist in the system and the effect of earnings transparency remains economically relevant and statistically significant at a $1 \%$ level.

\section{Table 11. Endogeneity tests}

\begin{tabular}{llll}
\hline & $(1)$ & $(2)$ & $(3)$ \\
& FE & FE_IV & 2S1S_IV \\
\hline Cons & $-0.460^{* * *}$ & $-0.493^{* * *}$ & $-1.015^{* * *}$ \\
& $(-10.37)$ & $(-9.53)$ & $(-13.66)$ \\
Trans & $0.018 * * *$ & $0.013 * *$ & $0.923 * * *$ \\
& $(2.93)$ & $(2.01)$ & $(3.08)$ \\
Control variables & Yes & Yes & Yes \\
Industry dummies & Yes & Yes & Yes \\
\hline Observations & 13793 & 11453 & 11453 \\
Adjusted R-squared & 0.252 & & 0.097 \\
Hausman(P value) & & 0.9996 & \\
Over-identifying (P value) & & 0.0000 &
\end{tabular}

Note 1: The table presents regression coefficients and t-statistics for Endogeneity tests by using fixed effect model, fixed effect model with adding instrument variables, two-period factors regression method with adding instrument variables, system GMM with adding instrument variables (earnings management index and lag of earnings transparency). The dependent variables are the total debt ratio.

Note2: $*, * *$ and $* * *$ denote statistical significance at $10 \%, 5 \%$ and $1 \%$ level for which the null hypothesis is rejected. Results for control variables are not reported but available upon request from the authors.

\subsection{Robustness tests}

\subsubsection{Controlling for equity finance}

Based on the Barth at al. (2013), earnings transparency is negatively related to the costs of capital, including both the cost of debt and cost of equity finance. Therefore, it is also possible that earnings transparency reduces the cost of equity finance for sample Chinese firms. Our conjecture is that creditors, i.e. lenders, are more concerned with earnings transparency which signals the creditability of borrowers, and therefore cost of debt finance is more sensitive to the 
improvement of earnings transparency than equity finance, thus leading an increase of leverage as shown earlier. To test such a conjecture, we control for the availability of equity finance by 'exceeded fund' which is measured by the difference between the expected amount of equity a sample firm would like to raise when IPO and the actual amount they raised. By controlling for the availability of equity finance, our baseline results on the favorable effects of earnings transparency on leverage (H1) still hold, as shown in Table 12. Our results show that exceed funds a sample firm received from stock markets reduce their demand for debt finance and therefore, lead to a lower leverage.

Table12. Earnings transparency and debt financing after controlling equity financing

\begin{tabular}{|c|c|c|c|}
\hline & (1) & (2) & (3) \\
\hline & Lev & Lev & Lev \\
\hline \multirow[t]{2}{*}{ Constant } & $-1.247 * * *$ & $-1.245 * * *$ & $-1.245 * * *$ \\
\hline & $(-11.84)$ & $(-11.82)$ & $(-11.84)$ \\
\hline \multirow[t]{2}{*}{ Trans } & $0.025^{*}$ & & \\
\hline & (1.94) & & \\
\hline \multirow[t]{2}{*}{ Transi } & & $0.050 * *$ & \\
\hline & & $(1.98)$ & \\
\hline \multirow[t]{2}{*}{ Transin } & & & 0.02 \\
\hline & & & $(1.35)$ \\
\hline \multirow[t]{2}{*}{ Exceeded Fund } & $-0.045 * * *$ & $-0.045 * * *$ & $-0.045 * * *$ \\
\hline & $(-10.14)$ & $(-10.26)$ & $(-10.19)$ \\
\hline Control variables & Yes & & Yes \\
\hline Industry dummies & Yes & & Yes \\
\hline Observations & 2661 & 2661 & 2661 \\
\hline Adjusted R-squared & 0.656 & 0.656 & 0.655 \\
\hline
\end{tabular}

\subsubsection{Alternative proxy of interest rate deregulation}

In order to ensure the consistency of above results and to show the strength of the marketoriented reform, we construct an alternative proxy for interest rate deregulation, IRdereg2, which is defined as the difference between market SHIBOR rates and controlled one-year base lending rate. Table 13 shows that the effect of earnings transparency remains economically 
relevant and its statistical significance is also confirmed at a $1 \%$ level on total debt ratio, which is consistent with our earlier findings.

Table 13. Alternative proxy of interest rate deregulation

\begin{tabular}{lccc}
\hline & $(1)$ & $(2)$ & $(3)$ \\
& Lev & Lev & Lev \\
\hline Cons & $-1.089 * * *$ & $-1.076^{* * *}$ & $-1.077 * * *$ \\
IRdereg2 & $(-16.19)$ & $(-16.05)$ & $(-16.01)$ \\
Trans & $-0.036^{* * *}$ & $-0.031 * * *$ & $-0.034 * * *$ \\
& $(-15.69)$ & $(-16.60)$ & $(-14.50)$ \\
IRdereg2*Trans & $0.146^{* * *}$ & & \\
& $(8.39)$ & & \\
Transi & $0.049 * * *$ & & \\
& $(6.03)$ & $0.179 * * *$ & $(6.88)$ \\
IRdereg2*Transi & & $0.053 * * *$ & $(6.26)$ \\
Transin & & $(5.55)$ & $0.070^{* * *}$ \\
IRdereg2*Transin & & & $(4.57)$ \\
Control variables & & & Yes \\
Industry dummies & & & Yes \\
\hline Observations & & Yes & 12661 \\
Adjusted R-squared & Yes & 12661 & 0.463 \\
\hline
\end{tabular}

Note1: The table presents regression coefficients and t-statistics (in parentheses) for robustness tests of alternative proxy of interest rate control (IRdereg2) by using a cluster analysis at the firm level for all samples with full set of controls. IRdereg 2 is calculated by the difference between market SHI

Note 2: All VIFs are lower than 10.*,** and *** denote statistical significance at $10 \%, 5 \%$ and $1 \%$ level for which the null hypothesis is rejected. Results for control variables are not reported but available upon request from the authors.

\subsubsection{Alternative proxy of earnings transparency}

Additionally, we retest Eq. (5) by replacing the proxy of earnings transparency with R-Squared synchronicity indicator $\left(R s q_{i, t}\right)$ (Table 11). $R s q_{i, t}$ is defined as $\log \left(R_{i, t}^{2} /\left(1-R_{i, t}^{2}\right)\right.$, where $R_{i, t}^{2}$ is the fitting rate $\mathrm{R}^{2}$ of stock price synchronism index model (Morck et al., 2000) ${ }^{2}$.The results

\footnotetext{
2 The systematic component of returns variation is large in emerging markets, and appears unrelated to fundamentals co-movement, consistent with noise trader risk.
} 
show that our main inference still hold. Hence, the effect of earnings transparency on corporate debt finance is not subject to the way of transparency is calculated.

Table 14. Alternative proxy of earnings transparency

\begin{tabular}{lcc}
\hline & $(1)$ & Lev \\
\hline Constant & Lev & $-0.921 * * *$ \\
& $-0.988^{* * *}$ & $(-14.47)$ \\
Rsq & $(-15.38)$ & $0.032 * * *$ \\
& $0.017 * * *$ & $(10.62)$ \\
IRdereg & $(6.65)$ & $-0.066^{* * *}$ \\
& & $(-16.38)$ \\
IRdereg*Rsq & & $0.023 * * *$ \\
& & $(5.01)$ \\
GDP growth & & $0.059 * *$ \\
& $0.532 * * *$ & $(2.15)$ \\
Control variables & $(18.04)$ & Yes \\
Industry dummies & Yes & Yes \\
\hline Observations & Yes & 13720 \\
Adjusted R-squared & 13720 & 0.470 \\
\hline
\end{tabular}

Note1: The table presents regression coefficients and t-statistics (in parentheses) for robustness tests of alternative proxy of earnings transparency (Rsq) by using a cluster analysis at the firm level for all samples with full set of controls. Additional control variable used is the GDP growth rate. The dependent variables are the total debt ratio.

Note 2: The multicollinearity is checked by VIFs that all are less than 10 . The $*, * *$ and $* * *$ denote statistical significance at $10 \%, 5 \%$ and $1 \%$ level for which the null hypothesis is rejected. Results for control variables are not reported but available upon request from the authors.

\subsubsection{Consider equity financing}

Our previous results suggest that earnings transparency has weak influence on equity financing in this section. To capture the impacts of interest rate deregulation on equity financing, we use equity financing ratio as dependent variables to measure the rates (the actual fund of equity financing/total assets) of sample firms. We apply a cluster analysis at firm level for all samples with a full set of control variables and report the results in Table 15. It shows that the effects of earnings transparency on the equity financing is weak positive. Therefore, our empirical results support the conjecture that earnings transparency improves leverage by reducing the cost of debt finance. 
Table 15. Earnings transparency and the equity financing

\begin{tabular}{lccc}
\hline & $(1)$ & $(2)$ & $(3)$ \\
& $\begin{array}{c}\text { Equity financing } \\
\text { ratio }\end{array}$ & Equity financing ratio & Equity financing ratio \\
\hline Constant & $2.091^{* * *}$ & $2.093^{* * *}$ & $2.068^{* * * *}$ \\
Trans & -10.49 & -10.45 & -10.53 \\
& $0.117^{*}$ & & \\
Transi & $(1.74)$ & & \\
& & -0.076 & $0.303 *$ \\
Transin & & $(-0.91)$ & $(2.77)$ \\
& & & Yes \\
Control variables & Yes & & Yes \\
Industry dummies & Yes & & Yes \\
Year dummies & Yes & 1153 & 1153 \\
\hline Observations & 1153 & 0.302 & 0.331 \\
Adjusted R-squared & 0.304 & & \\
\hline
\end{tabular}

Note1: The table presents regression coefficients and t-statistics (in parentheses) for tests of earnings transparency and the equity financing by using a cluster analysis at the firm level for all samples with full set of controls. The dependent variables are Equity financing ratio, which is calculated by the ratio of equity financing and asset.

Note 2: All VIFs are lower than 10.*,** and *** denote statistical significance at $10 \%, 5 \%$ and $1 \%$ level for which the null hypothesis is rejected. Results for control variables are not reported but available upon request from the authors.

We explicitly consider the impacts of interest rate deregulation by IRdereg and its interaction terms with earnings transparency measures. Similar to earlier results, the coefficients of interaction terms, are positive and not significantly, which means interest rate deregulation and earnings transparency has no effect on equity financing.

Table 16. Earnings transparency, interest rate deregulation and equity financing

\begin{tabular}{lccc}
\hline & $(1)$ & $(2)$ & $(3)$ \\
& Equity financing ratio & Equity financing ratio & $\begin{array}{c}\text { Equity financing } \\
\text { ratio }\end{array}$ \\
\hline Constant & $2.030^{* * *}$ & $2.027 * * *$ & $2.020^{* * *}$ \\
Irdereg & $(10.09)$ & $(10.06)$ & $(10.07)$ \\
& 0.039 & $0.060^{* * *}$ & $0.043^{*}$ \\
Trans & $(1.56)$ & $(2.67)$ & $(1.84)$ \\
& $0.102^{*}$ & & \\
Transi & $(1.78)$ & & \\
Transin & & 0.006 & $0.218^{* * *}$ \\
& & $(0.06)$ & $(2.63)$
\end{tabular}


IRdereg*Trans $\quad 0.107$

(0.75)

IRdereg*Transi

IRdereg*Transin

Control variables

Yes

Yes

Industry dummies

Yes

Yes

Observations 1153

1153

1153

Adjusted R-squared

0.287

0.283

0.294

Note 1: The table presents regression coefficients and t-statistics (in parentheses) for tests of earnings transparency, interest rate deregulation and the equity financing by using a cluster analysis at the firm level for all samples with full set of controls. The dependent variables are Equity financing ratio, which is calculated by the ratio of equity financing and asset.

Note 2: All VIFs are lower than 10. *,** and *** denote statistical significance at $10 \%, 5 \%$ and $1 \%$ level for which the null hypothesis is rejected. Results for control variables are not reported but available upon request from the authors.

\subsubsection{Using GLS and system GMM}

In order to make our results more robust, we test the results with general least squares. Table 17 shows the results that the effect of total earnings transparency, earnings transparency of industry and firms' own earnings transparency remain economically relevant and statistically significant at a $1 \%$ significance level. The results are basically consistent with the results on the basis of ordinary least square method

Table 17. Using General Least Squares

\begin{tabular}{llll}
\hline & $(1)$ & $(2)$ & $(3)$ \\
& GLS & GLS & GLS \\
\hline Cons & $-1.015^{* * *}$ & $-1.043 * * *$ & $-1.383^{* *}$ \\
Trans & $(-13.66)$ & $(-11.05)$ & $(-3.11)$ \\
& $0.035^{* * *}$ & & \\
Transi & $(5.99)$ & & \\
Transin & & $0.060 * * *$ & \\
& & $(4.11)$ & $0.037 * *$ \\
Control variables & & & $(4.59)$ \\
Industry dummies & Yes & Yes & Yes \\
\hline Observations & Yes & Yes & Yes \\
\hline
\end{tabular}

Note 1: The table presents regression coefficients and t-statistics for Endogeneity tests by using fixed effect model, fixed effect model with adding instrument variables, two-period factors regression method with adding instrument variables, system GMM with adding instrument variables (earnings management index and lag of earnings transparency). The dependent variables are the total debt ratio. 
Note2: $* * *$ and $* * *$ denote statistical significance at $10 \%, 5 \%$ and $1 \%$ level for which the null hypothesis is rejected. Results for control variables are not reported but available upon request from the authors.

In order to make our results more robust, we test the results with system GMM. Table 18 shows the results that the effect of total earnings transparency and firms' own earnings transparency remain economically relevant and statistically significant at a $10 \%$ significance level. The results are basically consistent with the results on the basis of ordinary least square method

\section{Table 18. Using system GMM}

\begin{tabular}{llll}
\hline & $(1)$ & $(2)$ & $(3)$ \\
& System GMM & System GMM & System GMM \\
\hline Cons & $-1.015^{* * *}$ & $-1.043^{* * *}$ & $-1.383^{* *}$ \\
Trans & $(-13.66)$ & $(-11.05)$ & $(-3.11)$ \\
& $0.0459 *$ & & \\
Transi & $(2.53)$ & & \\
& & 0.0353 & \\
Transin & & $(1.56)$ & $0.0510 *$ \\
& & & $(1.97)$ \\
Lev & & & $0.452 * * *$ \\
& & $0.433 * * *$ & $(4.33)$ \\
Control variables & $0.451 * * *$ & $(4.24)$ & Yes \\
Industry dummies & $(4.31)$ & Yes & Yes \\
\hline Observations & Yes & Yes & 1620 \\
Hausman(P value $)$ & Yes & 1620 & 0.0000 \\
Over-identifying (P value $)$ & 0.0000 & 0.0000 & 0.8986
\end{tabular}

Note 1: The table presents regression coefficients and t-statistics for Endogeneity tests by using fixed effect model, fixed effect model with adding instrument variables, two-period factors regression method with adding instrument variables, system GMM with adding instrument variables (earnings management index and lag of earnings transparency). The dependent variables are the total debt ratio.

Note2: $* * *$ and $* * *$ denote statistical significance at $10 \%, 5 \%$ and $1 \%$ level for which the null hypothesis is rejected. Results for control variables are not reported but available upon request from the authors.

\section{Conclusion and Implication}

This paper investigates the relationship between information transparency and debt financing behavior of Chinese listed firm. Our results are consistent with those reported in existing literature, such as Francis et al. (2004) and Zhang and Lu (2007), and suggest that informationally transparent firms have a higher debt ratio and lower effective interest costs on bank loans. In addition, this paper further explores the role played by interest rate deregulation 
in corporate finance, and in turn market fund allocation. We find that deregulation of interest rates allows firms to have a worse access to debt finance, and information transparency would moderate such an effect on corporate capital structure. This result supports the contemporary view on 'supply-side' effect and highlights the significant effects of new information in the hands of lenders on their ability to select better clients (De Janvry et al., 2010). Our results are robust to alternative proxies of key variables as well as additional controls of earnings quality, corporate credit risks. In addition, we shed new light on the interactions between earnings transparency and interest rate deregulation in the context of state owned firm, different economic growth target and different marketization level in each province of China.

Firstly, we examine the effects of state ownership, on corporate leverage in a setting of interest rate deregulation and find that SOEs have an advantage over private firms in accessing debt finance with interest rate deregulation. Secondly, we suggest that economic growth target is conducive to enhancing the transparency of the industry, but not the firm's own transparency. Secondly, we suggest that economic growth target is conducive to enhancing the transparency of the industry, but not the flirm's own transparency. Fourthly, we suggest that marketization in each province of China is conducive to enhancing firm's own transparency, but not the transparency of the industry.

It implies that state banks, SOEs and local governments are still the biggest players on both the demand and supply sides of the Chinese credit markets. However, it might take time for the new scheme to function properly, because banks, depositors, market participants and regulators all need to gain experience and adapt to the new regime. Therefore, the importance of this paper lies in the fact that first, it provides additional evidence on the effect of market-oriented reforms through how the information transparency interacts with the financial decisions making of corporations. Second, it offers policy implication to banking market deregulation in China. 
Our findings give rise to a number of important implications. First, we contribute to the literature on both the relation between financial disclosures and corporate financing (e.g. Barth et al., 2013) and the interaction between macroeconomic policies and micro-enterprise behaviors (e.g. Rao and Jiang, 2013). Second, a critical challenge to any economy is the allocation of limited resources to efficient investment opportunities. This paper provides evidence that SOEs have competitive advantages in accessing external finance against private and small businesses in China. This would be the target of banking market reform in order to bring a fair financing environment for all businesses in China. Third, our conclusion can suggest how the action of interest rate deregulation effect on financing cost and liquidity management, which is the supplementary conclusion based on the Campello et al. (2011).

With respect to further work, we aim to investigate how the earnings transparency has impact on the debt financing; and how such impact would depend on the openness of specific business, the cap of foreign shareholding and the convenience of investment in 2019. We also focus on the financing difficulties of SMEs. Doing so, would allow us to find a solution to the financing difficulties of SMEs in emerging economies which are similar to China. 


\section{References}

Acharya V V, Gale D, (2011). Yorulmazer T. Rollover risk and market freezes. The Journal of Finance, 66(4): 1177-1209.

Alti, A. (2006). How persistent is the impact of market timing on capital structure? Journal of Finance, 61(4), 1681-1710.

Baker, M. \& Wurgler, J. (2002). Market timing and capital structure. Journal of Finance, 57(1), $1-32$.

Barth, M. E., Konchitchki, Y. \& Landsman, W. R. (2013). Cost of capital and earnings transparency. Journal of Accounting and Economics, 55(2), 206-224.

Berger, P. G., Ofek, E. \& Yermack, D. L. (1997). Managerial entrenchment and capital structure decisions. Journal of Finance, 52(4), 1411-1438.

Bernanke, Ben S., and Mark Gertler. (1995). Inside the black box: the credit channel of monetary policy transmission. Journal of Economic perspectives 9.4: 27-48.

Bova F, Yang L. State - Owned Enterprises, Competition, and Disclosure[J]. Contemporary Accounting Research, 2018, 35(2): 596-621.

Booth, L., Aivazian, V., Demirguc-Kunt, V. \& Maksimovic, V. (2001). Capital structures in developing countries. Journal of Finance, 56(1), 87-130.

Botosan, C. A. (1997). Disclosure level and the cost of equity capital. The Accounting Review, 72(3), 323-349.

Brandt, L. \& Li, H. B. (2003). Bank discrimination in transition economies: Ideology, information, or incentives? Journal of Comparative Economics, 31(3), 387-413.

Brau, J. C. \& Fawcett, S. E. (2006). Initial public offerings: An analysis of theory and practice. Journal of Finance, 61(1), 399-436. 
Chen, D. H. \& Li, Z. (2015). Rural and city. China Journal of Accounting Research, 1, 4-14.

Chen, S. L. \& Ma, H. (2018). Loan availability and corporate commercial credit: quasi-natural experimental evidence of China's interest rate marketization reform. China Economic Research, 11, 108-120+149.

Chen, Y. B., Chen, X. L. \& Chen, W. Z. (2014). Interest rate control and the imbalance of aggregate demand structure. China Economic Research, 49(2), 18-31.

Campello M, Giambona E, Graham J R, et al. (2011). Liquidity management and corporate investment during a financial crisis. The Review of Financial Studies, 24(6): 1944-1979.

De Janvry, A., McIntosh, C. \& Sadoulet, E. (2010). The supply- and demand-side impacts of credit market information. Journal of Development Economics, 93(2), 173-188.

Di Maggio M, Kermani A, Keys B J, et al. (2017). Interest rate pass-through: Mortgage rates, household consumption, and voluntary deleveraging. American Economic Review, 107(11): $3550-88$.

Fan, J., Rui, O.M. \& Zhao, M. (2008). Public governance and corporate finance: evidence from corruption cases. Journal of Comparative Economics, 36(3), 343-364.

Feyzioğlu, T., Porther, N. \& Takáts, E. (2009) Interest rate liberalization in China. IMF Working Paper WP/09/171. http://papers.ssrn.com/sol3/papers.cfm?abstract_id=1457594

Firth, M., Lin, C., Liu, P. \& Wong, S. M. L. (2009). Inside the black box: bank credit allocation in China's private sector. Journal of Banking and Finance, 33(6), 1144-1155.

Francis, J., LaFond, R., Olsson, P. \& Schipper, K. (2004). Costs of equity and earnings attributes. The Accounting Review, 79(4), 967-1010. 
Frydman, R., Gray, C., Hessel, M. \& Rapaczymski, A. (1999). When does privatization work? The impact of private ownership on corporate performance in the transition economies. Quarterly Journal of Economics, 114(4), 1153-1191.

Gelos, R. G., Werner, A. M. (2002). Financial liberalization, credit constraints, and collateral: investment in $\mathrm{t}$

Goldstein I, Yang L. Good disclosure, bad disclosure[J]. Journal of Financial Economics, 2019, 131(1): 118-138.

Harris, M. \& Raviv, A. (1990). Capital structure and the informational role of debt. Journal of Finance, 45(2), 321-349.

Huang, G. and Song, F. M. (2006). The determinants of capital structure: evidence from China. China Economic Review, 17(1), 14-36.

Huang, Y. \& Wang, B. (2010). Cost distortions and structural imbalances in China. China and World Economy, 18(4), 1-17.

Jensen, M. C. \& Meckling, W. H. (1976). Theory of the firm: managerial behaviour, agency costs and ownership structure. Journal of Financial Economics, 3(4), 305-360.

Joseph, D. P \& Wong, T. J. (2012). Institutions and information environment of Chinese listed firms. In J. Fan, R. Morck \& B. Yeung (Ed.) Capitalizing China (pp. 201-242). Chicago: University of Chicago Press.

Kane, A., Marcus, A. J. \& McDonald, R. L. (1985). Debt policy and the rate of return premium to leverage. Journal of Financial and Quantitative Analysis, 20(4), 479-499.

Lambert, R., Leuz, C. \& Verrecchia, R. (2007). Accounting information, disclosure, and the cost of capital. Journal of Accounting Research, 45(2), 385-420. 
Li W.J., et al. (2018). Interest rate marketization and excessive debt reduction: dynamic adjustment of capital structure. China and World economy, 41(08):149-170.

Liu, Q., Tian, G. \& Wang, X. (2011). The effect of ownership structure on leverage decision: New evidence from Chinese listed firms. Journal of the Asia Pacific Economy, 16(2), 254276.

Modigliani, F. \& Miller, M. H. (1958). The cost of capital, corporation finance and the theory of investment. American Economic Review, 48, 261-297.

Morck, R., Yeung, B. \& Yu, W. (2000). The information content of stock markets: why do emerging markets have synchronous stock price movements? Journal of Financial Economics, 58(1-2), 215-260.

Öztekin Ö. (2015). Capital structure decisions around the world: which factors are reliably important?. Journal of Financial and Quantitative Analysis, 50(3): 301-323.

Petersen, M. A. (2009). Estimating standard errors in finance panel data sets: Comparing approaches. Review of Financial Studies, 22(1), 435-480.

Prawitt, D. F., Smith, J. L., \& Wood, D. A. (2009). Internal audit quality and earnings management. The Accounting Review, 84(4), 1255-1280.

Qian, Y., Tian, Y.\& Wirjanto, T. S. (2009). Do Chinese publicly listed companies adjust their capital structure toward a target level? China Economic Review, 20(4), 662-676.

Rajan, G. R. \& Zingales, L. (1995). What do we know about capital structure? Some evidence from international data. Journal of Finance, 50(5), 1421-1460.

Rao, P. \& Jiang, G. (2013). Credits Monetary policy, bank credit and accounting conservatism. Journal of financial research, 3(2), 51-71. 
Rao, P.G. \& Jiang, G.H. (2013). The impact of monetary policy on the relationship between bank loans and business. China Economic Research, 1, 68-82.

Stiglitz, J. \& Weiss, A. (1981). Credit rationing in markets with imperfect information. American Economic Review, 71(3), 393-410.

Tian, L., Han, L. \& Zhang, S. (2015). Business life cycle and capital structure: evidence from Chinese manufacturing firms. China and World Economy, 23(2), 22-39.

Wang, W. Z., Wang S. M. \& Zhu, W. X. (2011). Stock Market Financing Control and Company's Optimal Capital Structure. Management world, 401(2): 40-48.

Wang H.J., et al. (2018). Deregulation of Interest Rates, Excessive Debt and Debt Maturity Structure. Journal of Financial Research, 452(2): 100-117.

Xu, X. X. \& Liang, J. X. (2014). Strategical adjustment of Growth Target. China Economic Research, 1, 27-40.

Xu, X. X. \& Liu, Y. Y. (2017). Economic Growth Target Management. China Economic Research, 1, 18-33.

Xu, Y. (2007). Financing of private enterprises and deepening financial reform. In S. Lin \& X. Zhu (Ed.) Private Enterprises and China's Economic Development (pp.51-73). New York, NY: Routledge.

Zhang, C. \& Lu, W. (2007). Market focus and financing constraints. China Journal of Accounting Research, 11, 32-38.

Zhang, X. J., Li, C. \& Li, Yu. (2018). Distortions, growth catch-up and sustainable growth: reconsideration of the relationship between the Government and the Market. China Economic Research, 1, 4-20. 
Zhang, Y., Li, Z. J. \& Gong, L. T. (2014). Dual-track interest rate system, financial reform and the optimal monetary policy. China Economic Research, 10, 19-30.

Zhao X, Wang Z, Deng M. (2019). Interest Rate Marketization, Financing Constraints and R\&D Investments: Evidence from China. Sustainability 11, 2311.

Zheng, .M. N., Li, W. J., \& Liu, J. H. (2018). Interest Rate Liberalisation and Deleveraging of Over-indebted Enterprises: A Perspective on Capital Structure Dynamics. The Journal of World Economy, 8, 19-30. 